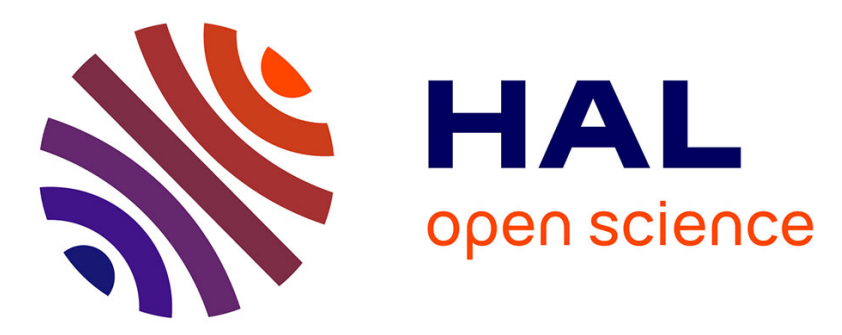

\title{
Synthesis of a novel pyrrolo-[3,2-c]quinoline N-oxide by aza-Baylis-Hillman adduct of o-nitrobenzaldehyde
} Evelina Colacino, Christophe Andre, Jean Martinez, Frédéric Lamaty

\section{To cite this version:}

Evelina Colacino, Christophe Andre, Jean Martinez, Frédéric Lamaty. Synthesis of a novel pyrrolo[3,2-c] quinoline N-oxide by aza-Baylis-Hillman adduct of o-nitrobenzaldehyde. Tetrahedron Letters, 2008, 49, pp.4953-4955. 10.1016/j.tetlet.2008.05.121 . hal-00292948

\section{HAL Id: hal-00292948 \\ https://hal.science/hal-00292948}

Submitted on 1 Feb 2021

HAL is a multi-disciplinary open access archive for the deposit and dissemination of scientific research documents, whether they are published or not. The documents may come from teaching and research institutions in France or abroad, or from public or private research centers.
L'archive ouverte pluridisciplinaire $\mathbf{H A L}$, est destinée au dépôt et à la diffusion de documents scientifiques de niveau recherche, publiés ou non, émanant des établissements d'enseignement et de recherche français ou étrangers, des laboratoires publics ou privés. 


\title{
Synthesis of a novel pyrrolo-[3,2-c]quinoline N-oxide by aza-Baylis-Hillman adduct of $o$-nitrobenzaldehyde
}

\author{
Evelina Colacino, Christophe André, Jean Martinez, Frédéric Lamaty * \\ Institut des Biomolécules Max Mousseron, UMR 5247 CNRS-Université Montpellier 1 et Université Montpellier 2, Place Eugène Bataillon, 34095 Montpellier cedex 05, France
}

Keywords:

Aza-Baylis-Hillman (aza-BH)

Ring closing metathesis (RCM)

3-Keto-pyrrole

Hexacyclic keto-nitrone

Reductive cyclization

Nitrone deoxygenation

\begin{abstract}
A B S T R A C T
A new and high yielding approach for the synthesis of a novel pyrrolo-[3,2-c]quinoline N-oxide is described. The key step consisted in the palladium-catalyzed reductive cyclization of an uncommon 3-ketopyrrole derivative of $o$-nitrobenzaldehyde, obtained in a straightforward manner through an aza-Baylis-Hillman/ring closing metathesis/aromatization reaction. A deoxygenation reaction of this novel pyrrolo-[3,2-c]quinoline $\mathrm{N}$-oxide afforded a new substituted pyrrolo-[3,2-c]quinoline analogue.
\end{abstract}

Organic N-oxides are useful intermediates for the synthesis of biologically active compounds. ${ }^{1,2}$ In particular, the quinoline Noxide core unit has been found in drugs exerting microsomal $\mathrm{Na}, \mathrm{K}-\mathrm{ATPa}$ e activity, ${ }^{3}$ protein kinase inhibition and anticancer, ${ }^{4}$ antiviral $^{5}$ or antimalarian activities. ${ }^{6,7}$ They have also relevant applications as spin traps in biological studies, ${ }^{8}$ and are efficient in age-related diseases, ${ }^{9}$ due to both in vitro and in vivo ${ }^{10}$ stability of resulting nitroxide radicals. The nitrone compound reacts with a free radical to form a derivative called spin adduct. Once the adduct is formed, it is relatively stable and the radical thus becomes inactivated and unable to interfere in biochemical processes and damage cellular tissues.

Considering the wide potential of the quinoline $\mathrm{N}$-oxide core unit, and as a part of our ongoing projects on the synthesis of heterocyclic structures by ring closing metathesis (RCM), ${ }^{11-14}$ we decided to explore the unprecedented preparation of pyrrolo[3,2-c]quinoline $\mathrm{N}$-oxide in only one step from a biarylic system constituted by an aryl-pyrrole in which a nitro group is in $\delta$-position with respect to the keto function. For this purpose, we extended our aza-Baylis-Hillman (aza-BH) reaction/ring closing metathesis/aromatization sequence to the preparation of an original 2-aryl-3-keto-substituted pyrrole. Aza-BH is a powerful reaction extensively exploited for the synthesis of multifunctional synthons in organic synthesis. ${ }^{15}$ It allows the formation of carbon-carbon bonds under mild reaction conditions and it consists

\footnotetext{
* Corresponding author. Tel.: +33 467143847; fax: +33 467144866

E-mail address: frederic.lamaty@univ-montp2.fr (F. Lamaty).
}

in the reaction between protected ammonia [usually with a sulfonyl group such as tosyl (Ts $\left.)^{11,16,17}\right]$, an aldehyde, and a $\alpha, \beta$-unsaturated carbonyl compound, catalyzed by nucleophilic Lewis bases such as 1,4-diazabicyclo[2,2,2]octane (DABCO).

The synthesis of 4-ethyl-1-methyl-1H-pyrrolo-[3,2-c]quinoline $\mathrm{N}$-oxide 9 is described in Scheme 1.

In the first step, the unsaturated $\beta$-aminoketone $\mathbf{4 a}$ was synthesized in a combined Lewis acid-[Ti( $\left.\mathrm{OiPr})_{4}\right]$ and base-catalyzed (DABCO) three component reaction involving commercial $p$-toluenesulfonamide $\mathbf{2}$ in the presence of an excess of $o$-nitrobenzaldehyde $\mathbf{1}$, and penten-2-one $\mathbf{3}$ as Michael acceptor. ${ }^{17}$ The reaction was performed at room temperature, with a moderate selectivity between the formation of $\beta$-aminoketone $\mathbf{4 a}$ (51\% yield) and $\beta$ hydroxyketone $\mathbf{4 b}$ ( $38 \%$ yield). A worse selectivity was obtained in the absence of Lewis acid. Extensive degradation of the crude was observed by running the reaction at a temperature of $100{ }^{\circ} \mathrm{C}$ using microwave irradiation (MW) for only $10 \mathrm{~min}$. This maybe due to the instability of the Michael acceptor under these conditions. We also performed the reaction under different conditions (DABCO in $i-\mathrm{PrOH}$ ) to drive the reaction to completion, but concomitant formation of the corresponding hydroxyester $\mathbf{4 b}$ was not avoided. All the attempts to separate $\mathbf{4 a}$ from $\mathbf{4 b}$ by crystallization at different temperatures and using different solvent combinations were unsuccessful, leading always to the degradation of the crude. $\beta$-Aminoketone 4 a was eventually recovered after purification by column chromatography and allylated with allyl bromide in a 'spot to spot' reaction in the presence of $\mathrm{K}_{2} \mathrm{CO}_{3}$ in $\mathrm{DMF}^{14}$ to yield $83 \%$ of the corresponding diene $\mathbf{5}$. The reaction was 


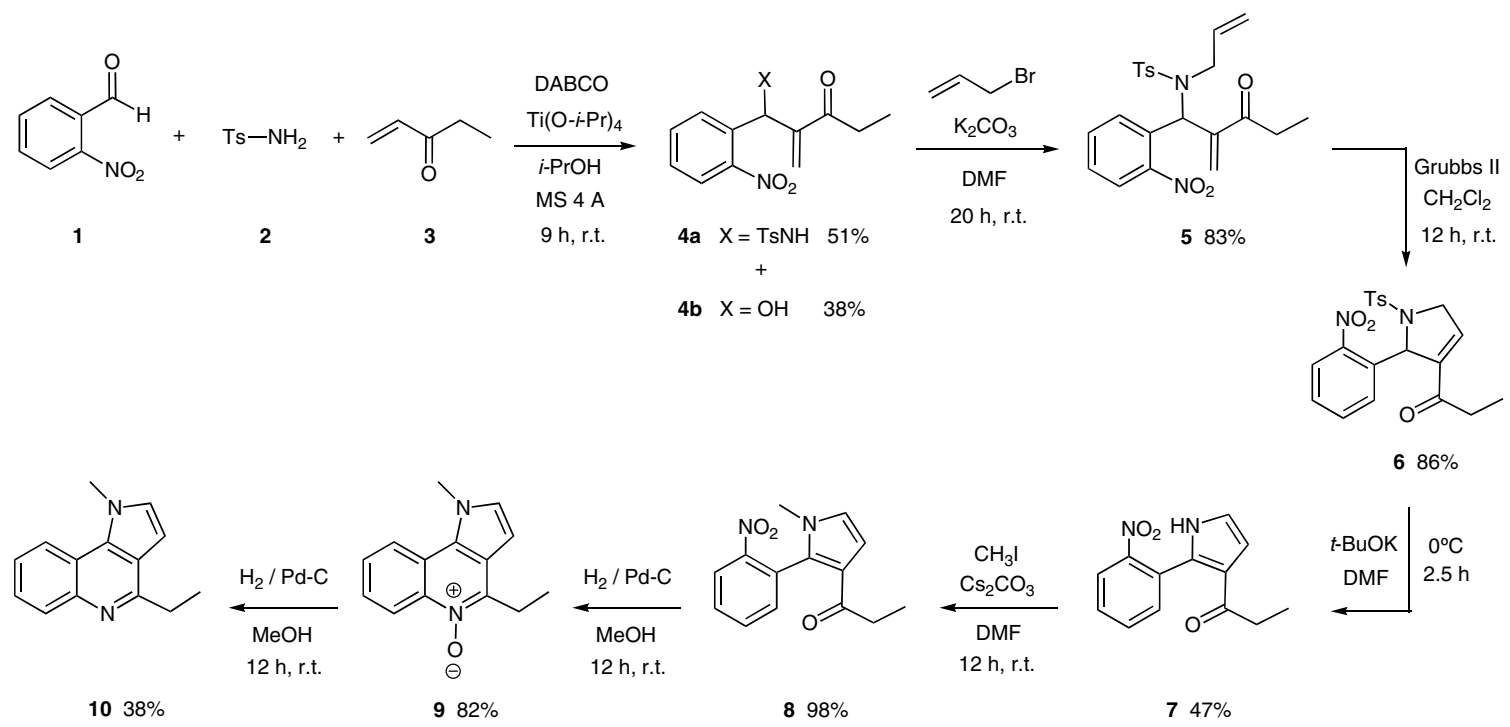

Scheme 1. Synthesis of 4-ethyl-1-methyl-1H-pyrrolo-[3,2-c]quinoline N-oxide $\mathbf{9}$.

performed either at room temperature within $12 \mathrm{~h}$ or under microwave irradiation at $100{ }^{\circ} \mathrm{C}$ for only $10 \mathrm{~min}$ without affecting the yield. After purification by chromatography, diene $\mathbf{5}$ was subsequently submitted to the ring closing metathesis ( $\mathrm{RCM}$ ) reaction known to be an efficient method for the synthesis of heterocyclic structures from linear precursors. ${ }^{18-21}$ Cyclization of diene $\mathbf{5}$ bringing to the novel conjugated cyclic enone $\mathbf{6}$ was complete within $12 \mathrm{~h}$ at room temperature using $5 \% 2$ nd generation air stable Grubbs' catalyst in good yield. Attempts to accelerate the reaction by microwave $\left(100^{\circ} \mathrm{C}, \mathrm{CH}_{2} \mathrm{Cl}_{2}\right)^{16}$ were unsuccessful, due to degradation of the starting material.

Few examples for the formation of 3-carboxy-substituted five membered heterocyclic alkenes through RCM reaction ${ }^{22-26}$ are reported, as well as their synthesis starting from aza-BH adducts, ${ }^{11,16,17,27,28}$ but none of them focus on the synthesis of 2-aryl-3-keto-substituted pyrrole according to this procedure.

The next step was cleavage of the tosyl group. ${ }^{29-31}$ Using $t$ BuOK in DMF at room temperature, $47 \%$ of the substituted pyrrole 7 was obtained within $2.5 \mathrm{~h}$ via elimination/aromatization steps. We supposed that the moderate yield resulted from the isomerization of pyrroline, or to secondary reactions involving the enol form of ketone. Then, pyrrole 7 was reacted with methyl iodide ${ }^{32}$ in the presence of $\mathrm{Cs}_{2} \mathrm{CO}_{3}$ in DMF to yield the corresponding methylated pyrrole $\mathbf{8}$ in high yield. Similar structures, in which a methyl group is used to protect pyrrole ring, have been synthesized to afford very potent antiviral, antibacterial and anticancer agents. ${ }^{33,34}$ Directly used without any purification, methyl-protected pyrrole 8 was hydrogenated at room temperature in methanol using $\mathrm{Pd} / \mathrm{C}$ under $\mathrm{H}_{2}$ atmosphere, ${ }^{35}$ yielding a very polar compound, which was identified as the stable hitherto unknown 4-ethyl-1-methyl-1H-pyrrolo-[3,2-c]quinoline $\mathrm{N}$-oxide $\mathbf{9}^{36}$ with the nitrone function confined to a ring structure in good yield, after purification by column chromatography. The conversion was not quantitative and $16 \%$ of the starting material was still present in the mixture, as determined by ${ }^{1} \mathrm{H}$ NMR of the crude. The synthesis of differently substituted quinoline $\mathrm{N}$-oxides has been described starting from the BaylisHillman adduct of $o$-nitrobenzaldehyde: in acidic medium, to access penta- ${ }^{37}$ or hexa-cyclic ${ }^{38,39}$ nitrones, or through an hydrogenation/cyclization cascade reaction, ${ }^{40}$ but no examples are reported for pyrrolo-quinoline $\mathrm{N}$-oxide structures.

When the hydrogenation reaction was prolonged for more than $12 \mathrm{~h}, \mathrm{~N}-\mathrm{O}$ hydrogenolysis/deoxygenation process occurred and a side reaction involving pyrrolo-quinoline $\mathrm{N}$-oxide $\mathbf{9}$ yielded imine
10 (Scheme 1). The last compound was recovered by column chromatography in a moderate yield, along with traces of the corresponding amine.

In conclusion, an efficient synthesis of 2-substituted-3-ketopyrrole has been developed, through a sequential aza-BH/ring closing metathesis/aromatization as a novel route to access to a novel hexacyclic nitrone, after palladium-catalyzed reductive cyclization. A deoxygenation reaction provides also an easy conversion into the imine. Biological tests are in progress to evaluate the full potential of the novel structure presented here.

\section{Acknowledgements}

We thank the CNRS and la Ligue contre le Cancer for financial support.

\section{References and notes}

1. Merino, P. Science of Synthesis; Padwa, A., Ed.; Thieme: Stuttgart, 2004; Vol. 27 pp 511-580.

2. Pyne, S. G.; Minyan, T. Curr. Org. Chem. 2005, 9, 1393-1418.

3. Andreev, V. P.; Korvacheva, E. G.; Nizhnik, Y. P. Pharm. Chem. J. 2006, 40, $347-$ 348.

4. Capraro, H.-G.; Furet, P.; Garcia-Echeverria, C.; Stauffer, F.; WO 2005054238 2005, p 138.

5. Albrecht, T.; Spleelman, D. J.; Sadagopa Ramanujam, V. M.; Lund, H. W.; Legator, M. S.; Trieff, N. M. Terat. Carcin. Mut. 1980, 1, 161-169.

6. Werbel, L. M.; Kersten, S. J.; Turner, W. R. Eur. J. Med. Chem. 1993, 28, 837852 .

7. Mouaddib, A.; Joseph, J.; Hasnaoui, A.; Mérour, Y.-J. Synthesis 2000, 4, 549-556

8. Zhang, H.; Joseph, J.; Vasquez-Vivar, J.; Karoui, H.; Nsanzumuhire, C.; Martàsek, P.; Tordo, P.; Kalyanaraman, B. FEBS Lett. 2000, 473, 58-62.

9. Floyd, R. A. Aging Cell 2006, 5, 51-57.

10. Green, A. R.; Ashwood, T.; Odergren, T.; Jackson, D. M. Pharmacol. Ther. 2003, $100,195-214$.

11. (a) Declerck, V.; Allouchi, H.; Martinez, J.; Lamaty, F. J. Org. Chem. 2007, 72, 1518-1521; (b) Benakki, H.; Colacino, E.; André, C.; Guenoun, F.; Martinez, J.; Lamaty, F. Tetrahedron 2008, 64, 5949-5955.

12. Varray, S.; Gauzy, C.; Lamaty, F.; Lazaro, R.; Martinez, J. J. Org. Chem. 2000, 65 , 6787-6790.

13. Varray, S.; Lazaro, R.; Martinez, J.; Lamaty, F. Eur. J. Org. Chem. 2002, 23082316.

14. Varray, S.; Lazaro, R.; Martinez, J.; Lamaty, F. Organometallics 2003, 22, 2426 2435.

15. Shi, Y.-L.; Shi, M. Eur. J. Org. Chem. 2007, 2905-2916.

16. Declerck, V.; Ribière, P.; Martinez, J.; Lamaty, F. J. Org. Chem. 2004, 69, 83728381.

17. Balan, D.; Adolfsson, H. Tetrahedron Lett. 2004, 45, 3089-3092.

18. Deiters, A.; Martin, S. F. Chem. Rev. 2004, 104, 2199-2238.

19. Felpin, F.-X.; Lebreton, J. Eur. J. Org. Chem. 2003, 3693-3712. 
20. Phillips, A. J.; Abell, A. D. Aldrichim. Acta 1999, 32, 75-90.

21. Donohoe, T. J.; Orr, A. J.; Bingham, M. Angew. Chem., Int. Ed. 2006, 45, 2664 2670.

22. Rhee, J. U.; Krische, M. J. Org. Lett. 2005, 7, 2493-2495.

23. Grigg, R: Martin, W.: Morris, J: Sridharan, V. Tetrahedron 2005, 61, 1138011392.

24. Grigg, R.; Hodgson, A.; Morris, J.; Sridharan, V. Tetrahedron Lett. 2003, 44, 1023 1026

25. Grigg, R.; Martin, W.; Morris, J.; Sridharan, V. Tetrahedron Lett. 2003, 44, 48994901.

26. Yang, S.-H.; Caprio, V. Synlett 2007, 1219-1222.

27. Kim, J. M.; Lee, K. Y.; Lee, S.; Kim, J. N. Tetrahedron Lett. 2004, 45, 2805-2808.

28. Yang, C.; Murray, W. V.; Wilson, L. J. Tetrahedron Lett. 2003, 44, 1783-1786.

29. Declerck, V.; Allouchi, H.; Martinez, J.; Lamaty, F. J. Org. Chem. 2007, 72, 3158.

30. Kundu, N. G.; Nandi, B. J. Org. Chem. 2001, 66, 4563-4575.

31. Nandi, B.; Kundu, N. G. Org. Lett. 2000, 2, 235-238.

32. Tao, Y. T.; Chen, M. L. J. Org. Chem. 1988, 53, 69-72.

33. Gerster, J. F.; Lindstrom, K. J.; Miller, R. L.; Tomai, M. A.; Birmachu, W.; Bomersine, S. N.; Gibson, S. J.; Imbertson, L. M.; Jacobson, J. R.; Knafla, R. T.; Maye, P. V. Nikolaides, N.; Oneyemi, F. Y.; Parkhurst, G. J.; Pecore, S. E.; Reiter, M. J.; Scribner, L. S.; Testerman, T. L.; Thompson, N. J.; Wagner, T. L.; Weeks, C. E.; Andre, J.-D. Lagain, D.; Bastard, Y.; Lupu, M. J. Med. Chem. 2005, 48, 3481-3491.

34. Kuyper, L. F.; Baccanari, D. P.; Jones, M. L.; Hunter, R. N.; Tansik, R. L.; Joyner, S S.; Boytos, C. M.; Rudolph, S. K.; Knick, V.; Wilson, H. R.; Caddell, J. M.;
Friedman, H. S.; Comley, J. C. W.; Stables, J. N. J. Med. Chem. 1996, 39, 892903.

35. Zschiesche, R.; Reissig, H.-U. Tetrahedron Lett. 1988, 29, 1685-1686.

36. Experimental procedure for the synthesis of 4-ethyl-1-methyl-1H-pyrrolo-[3,2clquinoline $\mathrm{N}$-oxide (9): To a solution of $\mathbf{8}(252 \mathrm{mg}, 0.98 \mathrm{mmol})$ in methanol $(100 \mathrm{~mL})$ was added palladium on charcoal $(10 \%, \mathrm{w} / \mathrm{w})$. The mixture was placed under hydrogen atmosphere. After $12 \mathrm{~h}$ at room temperature, the mixture was filtered over Celite and the Celite pad was washed with methanol. The solvent was evaporated and after column chromatography over silica gel and $\mathrm{AcOEt} / \mathrm{Et}_{2} \mathrm{O}$ (1/9 to $\left.2 / 8\right)$ as developing solvent yields $181 \mathrm{mg}(82 \%)$ of 9 as a white powder. Mp $168-172{ }^{\circ} \mathrm{C} ;{ }^{1} \mathrm{H}$ NMR $\left[\left(\mathrm{CD}_{3}\right)_{2} \mathrm{CO}, \mathrm{Me}_{4} \mathrm{Si}\right] \delta(\mathrm{ppm}): 8.85(\mathrm{~m}$, $1 \mathrm{H}), 8.41(\mathrm{~m}, 1 \mathrm{H}), 7.58(\mathrm{~m}, 2 \mathrm{H}), 7.31(\mathrm{~d}, J=3.1 \mathrm{~Hz}, 1 \mathrm{H}), 6.61(\mathrm{~d}, J=3.1 \mathrm{~Hz}, 1 \mathrm{H})$, $4.21(\mathrm{~s}, 3 \mathrm{H}), 3.21(\mathrm{q}, J=7.4 \mathrm{~Hz}, 2 \mathrm{H}), 1.25(\mathrm{t}, J=7.4 \mathrm{~Hz}, 3 \mathrm{H}) ;{ }^{13} \mathrm{C}$ NMR $\left[\left(\mathrm{CD}_{3}\right)_{2} \mathrm{CO}\right.$ $\left.\mathrm{Me}_{4} \mathrm{Si}\right] \delta(\mathrm{ppm}): 145.2,138.2,131.8,127.2,126.8,126.5,125.9,121.6,121.5$, 120.9, 119.2, 37.6, 22.1, 10.29; IR (KBr): 3415.7 (br), 2978.5 (w), 2216.8 (w), $1633.0(\mathrm{~m}), 1508.2(\mathrm{~s}), 1446.9(\mathrm{~m}), 1217.8(\mathrm{~s}), 1118.7(\mathrm{~m}), 1101.0(\mathrm{~s}), 1026.1$ (m), $903.4(\mathrm{~s}), 764.9(\mathrm{~s}) \mathrm{cm}^{-1}$; ESI-MS m/z $453.2[2 \mathrm{M}+\mathrm{H}]^{+} ; 227.0[\mathrm{M}+\mathrm{H}]^{+}$; $\mathrm{FAB}(+) \mathrm{m} / \mathrm{z} 227.1[\mathrm{M}+\mathrm{H}]^{+}$; HRMS calcd for $\mathrm{C}_{14} \mathrm{H}_{15} \mathrm{ON}_{2} 227.1184$; found: 227.1202 .

37. Lee, M. J.; Lee, K. Y.; Park, D. Y.; Kim, J. N. Bull. Korean Chem. Soc. 2005, 26, 1281 1285.

38. Kim, J. N.; Lee, K. Y.; Kim, H. S.; Kim, T. Y. Org. Lett. 2000, 2, 343-345.

39. Lee, K. Y.; Kim, J. M.; Kim, J. N. Tetrahedron 2003, 59, 385-390.

40. Familioni, O. B.; Kaye, P. T.; Klaas, P. J. Chem. Commun. 1998, 2563-2564. 